\title{
UPAYA PENINGKATAN PRESTASI BELAJAR DAN INTERAKSI SOSIAL SISWA MENGGUNAKAN MODEL PEMBELAJARAN GROUP INVESTIGATION (GI) BERBANTUAN MODUL PADA MATERI STOIKIOMETRI SISWA KELAS X-2 SMA ISLAM AHMAD YANI BATANG TAHUN PELAJARAN 2015/2016
}

\author{
Indah Qorina, Bakti Mulyani ${ }^{\star}$, dan Sulistyo Saputro \\ Program Studi Pendidikan Kimia, FKIP,Universitas Sebelas Maret, Surakarta, Indonesia
}

*Keperluan korespondensi, telp: 081393202573, email: baktimulyani@gmail.com

\begin{abstract}
ABSTRAK
Penelitian ini bertujuan untuk meningkatkan interaksi sosial dan prestasi belajar siswa kelas X-2 SMA Islam Ahmad Yani Batang pada materi pokok stoikiometri dengan menggunakan model pembelajaran Group Investigation (Gl) berbantuan modul. Penelitian ini merupakan Penelitian Tindakan Kelas (Classroom Action Research) yang dilaksanakan dalam dua siklus, setiap siklus terdiri dari perencanaan tindakan, pelaksanaan tindakan, observasi, dan refleksi. Subjek penelitian adalah siswa kelas X-2 SMA Islam Ahmad Yani Batang Tahun Pelajaran 2015/2016. Sumber data berasal dari guru dan siswa. Data diperoleh melalui angket, tes, observasi, wawancara, dan kajian dokumen. Teknik analisis data yang digunakan adalah analisis deskriptif kualitatif. Hasil penelitian menunjukkan bahwa penerapan model pembelajaran Group Investigation (Gl) berbantuan modul dapat meningkatkan interaksi sosial siswa pada materi stoikiometri kelas X-2 SMA Islam Ahmad Yani Batang Tahun Pelajaran 2015/2016 dengan persentase ketercapaian interaksi sosial siswa pada siklus I sebesar $77,27 \%$ menjadi $81,82 \%$ pada siklus II. Prestasi belajar siswa aspek kognitif mengalami peningkatan pada siklus I sebesar 40,9\% menjadi $72,73 \%$ pada siklus II, sedangkan prestasi belajar aspek afektif mengalami peningkatan sebesar $81,82 \%$ pada siklus I menjadi $86,36 \%$ pada siklus II.
\end{abstract}

Kata Kunci: Group Investigation, Modul, Interaksi Sosial, Prestasi Belajar, Stoikiometri.

\section{PENDAHULUAN}

Kualitas pendidikan menjadi salah satu tolok ukur kemajuan suatu bangsa. Oleh karena itu, terus dilakukan berbagai upaya untuk menyelesaikan masalah pendidikan yang ada sehingga kualitas pendidikan dapat ditingkatkan. Masalah pokok yang dihadapi dunia pendidikan di Indonesia adalah masalah yang berhubungan dengan mutu atau kualitas pendidikan yang masih rendah, yang salah satunya dapat dilihat dari rendahnya capaian daya serap siswa terhadap materi pelajaran. Berbagai upaya peningkatan kualitas pendidikan telah dilakukan, baik melalui peningkatan sarana dan prasarana, perubahan kurikulum, sistem pembelajaran melalui inovasi proses belajar mengajar, peningkatan kualitas guru, penyempurnaan sistem penilaian, dan usahausaha lain yang tercakup dalam komponen pendidikan.

Salah satu upaya pemerintah untuk meningkatkan mutu pendidikan adalah dengan melakukan pembaharuan kurikulum. Kurikulum yang digunakan pada sistem pembelajaran di Indonesia salah satunya adalah Kurikulum Tingkat Satuan Pendidikan (KTSP). Penerapan kurikulum ini dilandasi oleh UU No.20 Tahun 2003 tentang Sistem Pendidikan Nasional, PP No.19 Tahun 2005 tentang Standar Nasional Pendidikan, Kepmendiknas No.22 Tahun 2006, dan Kepmendiknas No.23 Tahun 2006. 
KTSP adalah kurikulum operasional yang disusun oleh dan dilaksanakan di masing-masing satuan pendidikan atau sekolah [1]. KTSP merupakan salah satu bentuk realisasi kebijakan desentralisasi di bidang pendidikan agar kurikulum benar-benar sesuai dengan kebutuhan pengembangan potensi peserta didik di sekolah yang bersangkutan di masa sekarang dan masa yang akan datang dengan mempertimbangkan kepentingan lokal, nasional, dan tuntutan global dengan semangat manajemen berbasis sekolah [2].

Selain kurikulum, sistem pembelajaran dalam dunia pendidikan saat ini merupakan salah satu komponen penting dalam peningkatan kualitas pendidikan di Indonesia. Diperlukan berbagai inovasi dalam proses belajar mengajar untuk menghasilkan situasi belajar mengajar yang kondusif agar tujuan pembelajaran dapat tercapai. Oleh karena itu, keterampilan dan kreativitas dari pendidik maupun dari peserta didik sangat diperlukan untuk mencapai hasil yang maksimal dalam dunia pendidikan, karena pada dasarnya keberhasilan dalam suatu pembelajaran sangat dipengaruhi oleh kolaborasi antara peserta didik dengan pendidik. Keduanya harus bisa saling berkolaborasi untuk bisa menciptakan suasana belajar yang menyenangkan sehingga dapat membangkitkan semangat belajar siswa dan mendorong siswa untuk memperoleh prestasi yang baik.

SMA Islam Ahmad Yani Batang merupakan salah satu sekolah swasta di Kabupaten Batang yang menerapkan KTSP. Berdasarkan observasi dan wawancara terhadap guru serta siswa, dapat diidentifikasi permasalahanpermasalahan sebagai berikut:

1. Pelajaran kimia di SMA Islam Ahmad Yani masih melakukan pembelajaran berpusat pada guru (Teacher Centered Learning), dimana guru menyampaikan materi pelajaran kepada siswa menggunakan metode ceramah. Proses belajar mengajar masih berlangsung satu arah, dimana guru yang lebih aktif memberikan informasi kepada siswa, sedangkan siswa cenderung pasif dan hanya mendengarkan materi pelajaran.

2. Siswa menginginkan cara mengajar selain metode ceramah agar terdapat variasi dalam belajar sehingga tidak merasa jenuh dan pembelajaran kimia berlangsung lebih menyenangkan.

3. Partisipasi siswa yang rendah, karakter siswa $\mathrm{X}-2$ yang cenderung individualistis, dan kurangnya kerja sama antarsiswa dalam kelompok. Sehingga, dapat dikatakan bahwa interaksi sosial yang berlangsung di kelas relatif rendah. Hal ini didukung dengan capaian angket interaksi sosial pra siklus kategori sangat tinggi dan tinggi hanya sebesar $54,54 \%$. Padahal, interaksi sosial dapat memberikan dukungan dan refleksi yang berpengaruh terhadap proses dan hasil pembelajaran [3].

4. Kondisi ekonomi keluarga siswa yang cenderung menengah ke bawah menyebabkan siswa tidak mampu membeli buku, sehingga buku yang dimiliki hanya buku dari sekolah yang harus dipinjam.

5. Pada umumnya banyak siswa yang masih sulit memahami dan menguasai konsep pada materi kimia, salah satunya stoikiometri, dimana materi tersebut termasuk materi yang rumit, abstrak, dan membutuhkan perhitungan matematis sehingga banyak siswa yang kesulitan dalam belajar. Materi stoikiometri merupakan salah satu materi dengan tingkat ketuntasan yang rendah pada tahun pelajaran 2013/2014 dan 2014/2015 berturutturut sebesar $36,25 \%$ dan $37,5 \%$.

Salah satu upaya untuk meningkatkan prestasi belajar dan interaksi sosial siswa SMA Islam Ahmad Yani Batang adalah melalui Penelitian Tindakan Kelas (PTK) atau Classroom Action Research (CAR). Penelitian tindakan dalam pendidikan merupakan sebuah metode penelitian kualitatif yang mendorong para praktisi (pengajar/guru) menjadi reflektif dalam praktik mengajar, dengan tujuan lebih meningkatkan atau memperbaiki sistem mengajarnya [4]. Menurut definisi lain, PTK merupakan suatu pencermatan terhadap kegiatan belajar berupa sebuah tindakan, yang sengaja dimunculkan dan 
terjadi dalam sebuah kelas secara bersama [5].

PTK pada penelitian ini dilakukan dengan penerapan model pembelajaran kooperatif. Model pembelajaran kooperatif yang dilakukan dalam kelompok kecil memungkinkan adanya kerja sama, perasaan saling memiliki, dan saling membantu [6]. Salah satu model pembelajaran kooperatif adalah Group Investigation (GI). Gl merupakan suatu model pembelajaran yang mengakomodasi peserta didik untuk belajar melalui model belajar kelompok, sehingga diharapkan peserta didik lebih leluasa dalam menyampaikan pemahaman mereka terkait materi ajar. Langkahlangkah dalam penerapan model pembelajaran GI sebagai berikut [7]:

a) mengidentifikasikan topik dan mengatur siswa ke dalam kelompok,

b) merencanakan tugas yang akan dipelajari,

c) melaksanakan investigasi,

d) menyiapkan laporan akhir,

e) mempresentasikan laporan akhir, dan

f) evaluasi.

Penerapan model GI dapat meningkatkan prestasi belajar [8]. Penelitian lain menunjukkan bahwa model pembelajaran Group Investigation (GI) lebih efektif untuk meningkatkan prestasi belajar siswa dibandingkan dengan Teacher Centered Learning [9]. Selain itu, sudah dilakukan penelitian sebelumnya bahwa penerapan Gl dapat meningkatkan kerjasama dan prestasi belajar siswa [10].

Berdasarkan pengamatan terhadap permasalahan yang ada, beberapa rujukan penelitian sebagai alternatif pemecahan masalah, maka dapat dilakukan upaya perbaikan kualitas pendidikan dengan menggunakan model pembelajaran Group Investigation (Gl) berbantuan modul untuk meningkatan prestasi belajar dan interaksi sosial siswa pada materi stoikiometri siswa kelas X-2 SMA Islam Ahmad Yani Batang tahun pelajaran 2015/2016.

\section{METODE PENELITIAN}

Penelitian ini dilakukan di kelas X-2 SMA Islam Ahmad Yani, yang beralamat di Jalan Kyai Surgi Proyonanggan Selatan Kabupaten Batang. Penelitian ini menggunakan metode Penelitian Tindakan Kelas (PTK) yang dilaksanakan sebanyak dua siklus. Setiap siklus memiliki empat tahap, yaitu tahap perencanaan, tindakan, observasi, dan refleksi. Subjek penelitian adalah siswa kelas X-2 SMA Islam Ahmad Yani Batang tahun pelajaran 2015/2016. Sumber data berasal dari guru dan siswa.

Teknik pengumpulan data dilakukan melalui dua metode, yaitu metode tes dan non tes. Metode tes untuk penilaian prestasi belajar aspek kognitif. Metode non tes untuk penilaian melalui observasi, wawancara, kajian dokumen, angket aspek afektif, dan interaksi sosial. Teknik analisis kualitatif yang dilakukan meliputi tiga komponen, yaitu reduksi data, penyajian data, dan penarikan kesimpulan [11].

Teknik yang digunakan untuk memeriksa validitas dari data yang dihasilkan adalah triangulasi, yaitu teknik pemeriksaan data yang memanfaatkan sesuatu yang lain di luar data, untuk keperluan pengecekan atau sebagai pembanding terhadap data. Dalam penelitian ini, teknik triangulasi yang digunakan adalah triangulasi metode. Teknik triangulasi adalah metode yang dilakukan dengan mengumpulkan data tetap dari sumber data yang berbedabeda [12]. Pada penelitian ini, pengumpulan data dilakukan melalui observasi, wawancara dan angket belajar siswa.

\section{HASIL DAN PEMBAHASAN}

Penelitian ini menggunakan metode Penelitian Tindakan Kelas (PTK) yang dilaksanakan sebanyak dua siklus. Setiap siklus memiliki empat tahap, yaitu tahap perencanaan, tindakan, observasi, dan refleksi.

\section{Siklus I}

\section{a. Perencanaan Tindakan}

Pada tahap perencanaan, peneliti menyusun beberapa instrumen penelitian, antara lain silabus, Rencana Pelaksanaan Pembelajaran (RPP), dan 
media pembelajaran, dan instrumen penilaian. Untuk silabus, peneliti bekerja sama dengan guru menyusun silabus yang disesuaikan dengan kurikulum KTSP, kondisi, dan indikator yang diterapkan di SMA Islam Ahmad Yani Batang. Berdasarkan silabus, dikembangkan lagi untuk menyusun RPP. Media pembelajaran yang digunakan adalah modul, yang disesuaikan dengan sintaks model GI dengan memperhatikan struktur dan indikator prestasi belajar dan interaksi sosial yang ingin dicapai. Tahap selanjutnya adalah menyusun instrumen penilaian, yang terdiri dari penilaian prestasi belajar dan interaksi sosial. Prestasi belajar meliputi aspek kognitif berupa tes objektif, dan aspek afektif berupa angket serta lembar observasi. Penilaian interaksi sosial berupa angket dan lembar observasi.

\section{b. Pelaksanaan Tindakan}

Pelaksanaan tindakan siklus I di kelas X-2 SMA Islam Ahmad Yani Batang tahun pelajaran 2015/2016 berupa serangkaian kegiatan belajar mengajar dengan berpedoman pada sintaks model pembelajaran Gl yang terdapat pada RPP yang telah disusun sebelumnya. Pelaksanaan tindakan pada siklus I dilakukan sebanyak lima kali pertemuan dengan alokasi waktu 2 x 45 menit, dan satu kali pertemuan untuk ujian siklus I. Langkah awal pembelajaran yang dilakukan guru adalah apersepsi, motivasi, dan penyampaian tujuan pembelajaran yang dilakukan pada tiap pertemuan. Setelah itu, guru memberikan penjelasan singkat mengenai materi dan pembagian materi dan lembar diskusi untuk tiap kelompok.

Siswa berdiskusi dalam kelompoknya untuk memahami materi dan menyelesaikan lembar diskusi. Siswa menggunakan modul, buku paket, maupun akses internet untuk membantu memahami materi. Guru mengatur kegiatan siswa agar kondusif. Selanjutnya, setiap kelompok mempresentasikan materinya masing-masing, saling tanya jawab, dan menjelaskan materi dan jawaban soal dari lembar diskusi. Setelah semua kelompok selesai presentasi, guru mengevaluasi kegiatan pembelajaran, kemudian bersama siswa menyimpulkan hasil pelajaran.

\section{c. Observasi Tindakan}

Observasi tindakan dilakukan selama proses pembelajaran berlangsung, dari pertemuan pertama hingga evaluasi siklus I. Pengamatan terhadap siswa dilakukan selama proses pembelajaran berlangsung. Pada awal pembelajaran, siswa masih belum terbiasa dengan model pembelajaran GI yang terlihat dari kebingungan beberapa siswa saat diadakan diskusi kelompok. Pada diskusi yang pertama, belum ada kelompok yang semua anggotanya aktif, karena belum ada pembagian tugas yang baik. Pada saat setiap kelompok maju mempresentasikan hasil diskusinya, masih tampak canggung dan saling meminta temannya untuk presentasi, sehingga guru masih harus mengkondisikan siswa agar presentasi berjalan lancar. Pada diskusi yang berikutnya, siswa sudah mulai terbiasa dan mengerti apa yang harus mereka kerjakan sehingga pengkondisian siswa tidak memerlukan waktu yang banyak.

Siswa sudah cukup aktif berdiskusi dalam kelompoknya dan bersama-sama mengerjakan soal diskusi, kemudian mempresentasikan dan saling tanya jawab berlangsung dengan baik sehingga kelas menjadi aktif dan kondusif untuk menciptakan adanya interaksi sosial yang tinggi. Tujuan dari belajar dalam kelompok kecil pun telah tercapai dimana siswa yang telah memahami materi mengajarkan kepada teman-temannya yang masih kurang mengerti sehingga semua anggota kelompok dapat menguasai materi tersebut.

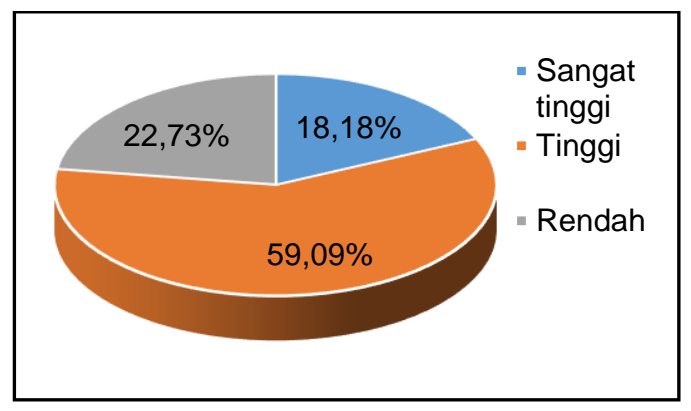

Gambar 1. Hasil Akhir Interaksi Sosial Siswa Siklus I 
Hasil yang diperoleh pada interaksi sosial siswa tercantum dalam Gambar 1. Berdasarkan Gambar 1, diperoleh bahwa siswa yang memiliki interaksi sosial kategori sangat tinggi sebesar $18,18 \%$ dan kategori tinggi sebesar 59,09\%. Sehingga, berdasarkan kategori minimal yang harus dicapai adalah kategori tinggi, maka persentase ketercapaian interaksi sosial siswa siklus I sebesar $77,27 \%$.

Hasil yang diperoleh untuk prestasi belajar aspek kognitif tercantum dalam Tabel 1. Berdasarkan Tabel 1, diketahui ketuntasan belajar siswa aspek kognitif sebesar 40,9\%. Hasil ini belum mencapai target yang telah ditetapkan yaitu $60 \%$. Untuk hasil prestasi belajar aspek afektif tercantum pada Gambar 2. Berdasarkan Gambar 2, diperoleh bahwa siswa yang memiliki afektif kategori sangat tinggi sebesar $13,64 \%$ dan kategori tinggi sebesar $68,18 \%$. Sehingga, berdasarkan kategori minimal yang harus dicapai adalah kategori tinggi, maka persentase ketercapaian prestasi belajar aspek afektif siklus I sebesar $81,82 \%$.

Tabel 1.Hasil Prestasi Belajar Aspek Kognitif Stoikiometri Siklus I

\begin{tabular}{cc}
\hline Kategori & Capaian (\%) \\
\hline Tuntas & 40,90 \\
Tidak Tuntas & 50,10 \\
\hline
\end{tabular}

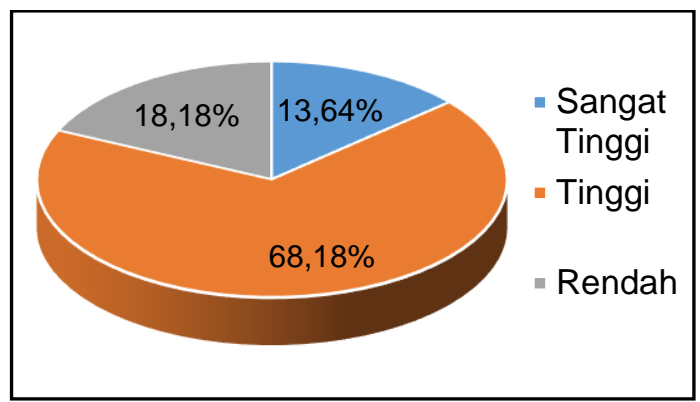

Gambar 2. Hasil Akhir Afektif Siswa Siklus I

\section{d. Refleksi Tindakan}

Pembelajaran pada tindakan I dilaksanakan agar siswa menguasai materi pokok stoikiometri. Pada siklus I, terdapat perubahan hasil observasi pada setiap pertemuan, dimana pada umumnya terdapat peningkatan baik pada kemampuan interaksi sosial siswa maupun pada aspek afektif. Setelah pelaksanaan tindakan I selesai, diadakan tes siklus I untuk mengetahui capaian prestasi belajar dan interaksi sosial siswa pada materi stoikiometri. Pada aspek kognitif, hasil yang diperoleh sebesar $40,9 \%$ belum memenuhi target yang telah ditetapkan, yaitu $60 \%$. Hasil interaksi sosial siswa dan prestasi belajar aspek afektif pada siklus I sudah mencapai target, meskipun terdapat beberapa indikator yang belum tercapai.

\section{Siklus II}

\section{a. Perencanaan Tindakan}

Guru menyusun RPP sesuai dengan indikator kompetensi yang belum tercapai. Pertemuan pada siklus II direncanakan sebanyak 3 kali pertemuan dengan waktu 2x45 menit, dengan satu kali pertemuan untuk ujian siklus II. Tindakan pada siklus II lebih difokuskan untuk penyempurnaan dan perbaikan terhadap kendala-kendala yang terdapat pada siklus I. Adapun kendala yang ada pada siklus I adalah masih belum tercapainya aspek kognitif. Pada siklus II, guru memberikan tugas kepada siswa untuk mempelajari dan mengerjakan latihan soal pada modul untuk indikator yang masih belum tercapai.

\section{b. Pelaksanaan Tindakan}

Pelaksanaan pembelajaran pada pertemuan pertama dan kedua, dilakukan dengan mengawali pembelajaran melalui pemberian apersepsi, motivasi, dan tujuan pembelajaran. Pada proses pembelajaran, guru menekankan konsep-konsep pokok pada indikator yang belum tercapai pada siklus I berdasarkan hasil analisis dari refleksi pada tindakan I. Pada siklus II, masingmasing kelompok mendengarkan penjelasan guru dengan bantuan modul sebagai buku pegangan siswa. Guru menjelaskan tentang volum molar, kemolaran larutan, penentuan rumus molekul dan rumus empiris, serta penentuan rumus hidrat (air kristal). Setelah itu, diadakan diskusi kelompok. Guru menekankan kepada siswa agar 
lebih aktif berdiskusi, meningkatkan kerjasama, dan saling membantu dalam kelompok, serta menanyakan hal-hal yang belum dipahami. Pada siklus II, guru mengecek hasil kerja siswa untuk mengerjakan latihan soal pada modul siswa.

\section{c. Observasi Tindakan}

Pada siklus II, siswa sudah terbiasa dengan model Gl sehingga pengkondisian untuk memulai pelajaran lebih mudah. Siswa lebih aktif berdiskusi dalam kelompoknya dan bersama-sama mengerjakan soal diskusi, kemudian presentasi dan saling tanya jawab sudah yang berlangsung baik sehingga diharapkan interaksi sosial dapat mengalami peningkatan. Guru menjelaskan materi yang masih kurang dikuasai siswa. Pada siklus II, tujuan dari belajar dalam kelompok kecil pun telah tercapai dimana siswa yang telah memahami materi berusaha menjelaskan kepada temantemannya yang masih kurang mengerti sehingga semua anggota kelompok dapat menguasai materi tersebut.

Hasil akhir interaksi sosial siswa terdapat pada Gambar 3. Berdasarkan Gambar 3, diperoleh bahwa siswa yang memiliki interaksi sosial kategori sangat tinggi sebesar $31,82 \%$ dan kategori tinggi sebesar $50 \%$. Sehingga, berdasarkan kategori minimal yang harus dicapai adalah kategori tinggi, maka persentase ketercapaian interaksi sosial siswa siklus II sebesar $81,82 \%$.

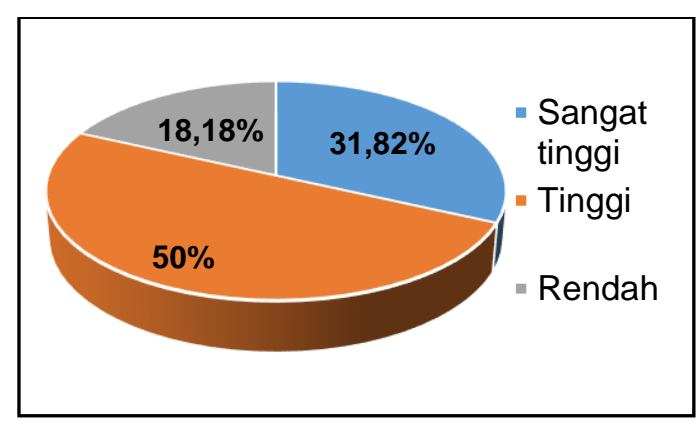

Gambar 3. Hasil Akhir Interaksi Sosial Siswa Siklus II
Hasil yang diperoleh untuk prestasi belajar aspek kognitif tercantum dalam Tabel 2. Berdasarkan Tabel 2, diketahui ketuntasan belajar siswa aspek kognitif sebesar 40,9\%. Hasil ini belum mencapai target yang telah ditetapkan yaitu $60 \%$. Untuk hasil prestasi belajar aspek afektif tercantum pada Gambar 2. Berdasarkan Gambar 2, diperoleh bahwa siswa yang memiliki afektif kategori sangat tinggi sebesar $27,27 \%$ dan kategori tinggi sebesar $59,09 \%$. Sehingga, berdasarkan kategori minimal yang harus dicapai adalah kategori tinggi, maka persentase ketercapaian prestasi belajar aspek afektif siklus I sebesar $86,36 \%$.

Tabel 2.Hasil Prestasi Belajar Aspek Kognitif Stoikiometri Siklus II

\begin{tabular}{cc}
\hline Kategori & Capaian (\%) \\
\hline Tuntas & 72,73 \\
Tidak Tuntas & 27,27 \\
\hline
\end{tabular}

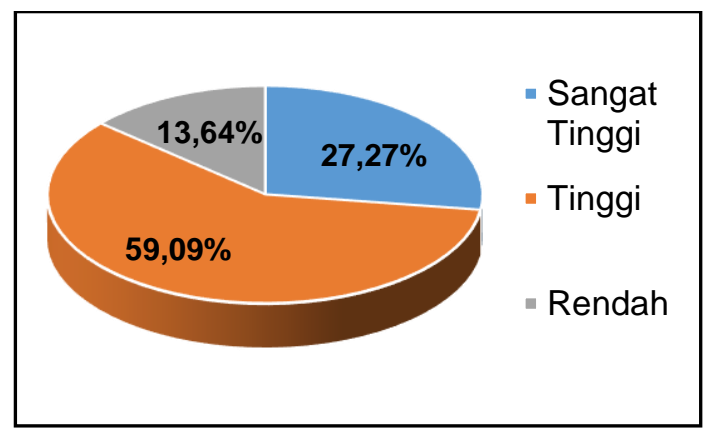

Gambar 4. Hasil Akhir Interaksi Sosial Siswa Siklus II

\section{d. Refleksi Tindakan}

Pembelajaran pada tindakan II dilaksanakan dengan tujuan utama pada penguasaan materi pokok stoikiometri, dimana target aspek kognitif pada siklus I sebesar $60 \%$ belum tercapai. Pada siklus II, aspek kognitif, afektif, maupun interaksi sosial telah memenuhi target yang ditetapkan. Capaian interaksi sosial siswa $81,82 \%$, prestasi belajar aspek kognitif sebesar $72,73 \%$, sedangkan capaian prestasi belajar aspek afektif sebesar $86,36 \%$. 


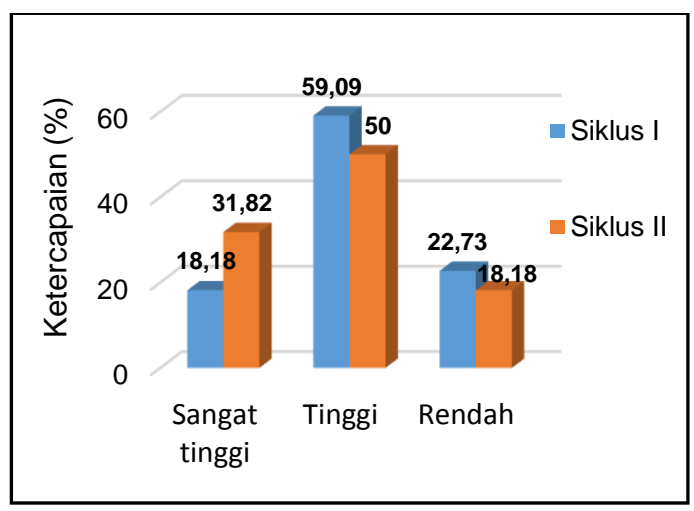

Gambar 5. Perbandingan Interaksi Sosial Siswa Siklus I dan II

\section{Perbandingan Antar Siklus}

Berdasarkan hasil angket interaksi sosial pra siklus, ketercapaian sebesar $54,54 \%$, dengan peningkatan sebesar $22,73 \%$ setelah tindakan siklus I. Berdasarkan Gambar 5, dari siklus I ke siklus II terjadi peningkatan sebesar $13,64 \%$ untuk kategori sangat tinggi, penurunan $9,09 \%$ pada kategori tinggi, dan penurunan sebesar $4,55 \%$ pada kategori rendah. Hal ini menunjukkan adanya peningkatan ketercapaian siswa aspek interaksi sosial pada setiap dilakukan tindakan.

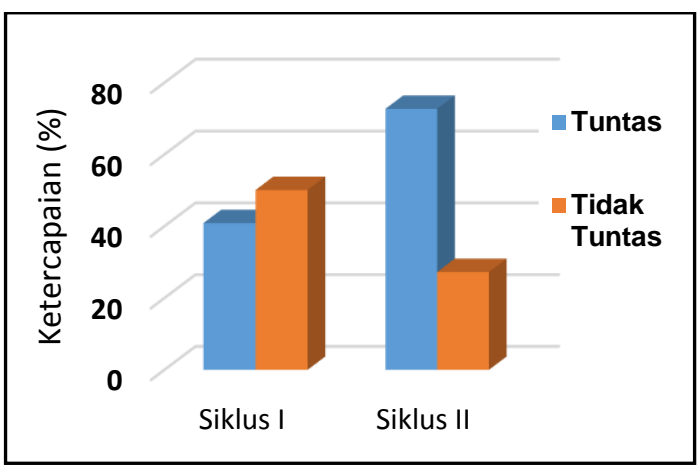

Gambar 6. Perbandingan Hasil Prestasi Belajar Aspek Kognitif Siklus I dan Siklus II

Berdasarkan Gambar 6, dari siklus I ke siklus || ketuntasan belajar siswa mengalami peningkatan sebesar $31,83 \%$. Sedangkan capaian aspek afektif siswa tercantum dalam Gambar 7, dari siklus I ke siklus II terjadi peningkatan sebesar 13,63\% untuk kategori sangat tinggi, penurunan $9,09 \%$ pada kategori tinggi, dan $4,54 \%$ pada kategori rendah.

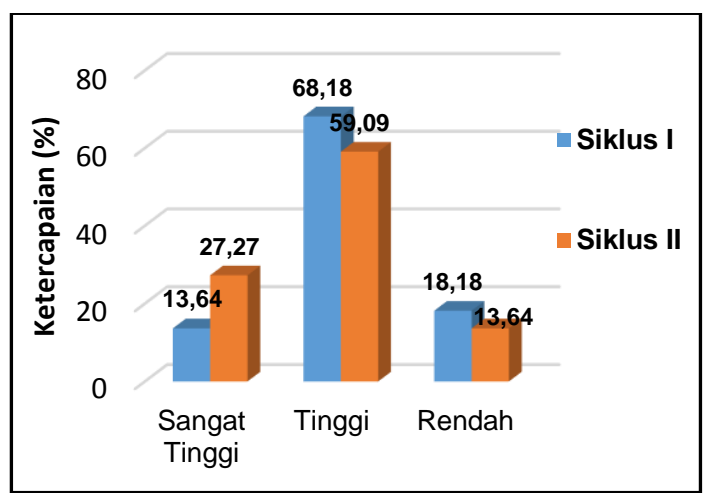

Gambar 7. Perbandingan Aspek Afektif Siswa Siklus I dan Siklus II

Pada penelitian ini, terdapat peningkatan baik pada aspek interaksi sosial maupun pada aspek prestasi belajar siswa. Hasil ini sesuai dengan beberapa penelitian sebelumnya, dimana terdapat pengaruh antara interaksi sosial siswa dengan prestasi belajar [13] [14].

\section{KESIMPULAN}

Berdasarkan hasil penelitian, menunjukkan bahwa penerapan model pembelajaran Group Investigation (Gl) berbantuan modul dapat meningkatkan interaksi sosial siswa pada materi stoikiometri kelas X-2 SMA Islam Ahmad Yani Batang Tahun Pelajaran 2015/2016 dengan persentase ketercapaian interaksi sosial siswa pada siklus I sebesar $77,27 \%$ menjadi $81,82 \%$ pada siklus II. Prestasi belajar siswa aspek kognitif mengalami peningkatan pada siklus I sebesar $40,9 \%$ menjadi $72,73 \%$ pada siklus II, sedangkan prestasi belajar aspek afektif mengalami peningkatan sebesar $81,82 \%$ pada siklus I menjadi $86,36 \%$ pada siklus II.

\section{UCAPAN TERIMA KASIH}

Dalam kesempatan ini, peneliti mengucapkan terima kasih dan penghargaan yang sebesar-besarnya kepada Ibu Dra. Sri Suharsih, M.Si., selaku Kepala SMA Islam Ahmad Yani Batang yang telah memberikan izin dan untuk mengadakan penelitian di lingkungan SMA Islam Ahmad Yani Batang. Bapak Bhakti Kharismawan, S.Pd. selaku guru mata pelajaran kimia 
SMA Islam Ahmad Yani Batang, yang telah memberikan bimbingan dan membantu dalam penelitian ini.

\section{DAFTAR RUJUKAN}

[1] Badan Standar Nasional Pendidikan, 2006, Panduan Penyusunan Kurikulum Tingkat Satuan Pendidikan Jenjang Pendidikan Dasar dan Menengah, Jakarta: BSNP.

[2] Halimah, L., Rostika, D., \& Sudirjo, E., 2009, Jurnal Pendidikan Dasar Eduhumaniora, 1(1): 1-11.

[3] Wang, H., 2005, International Journal of Technology in Teaching and Learning, 1 (2): 79-88.

[4] Kesuma, A.T., 2013, Menyusun PTK Itu Gampang, Jakarta: Erlangga.

[5] Arikunto, S., Suhardjono., \& Supardi., 2006, Penelitian Tindakan Kelas, Jakarta: PT Bumi Aksara.

[6] Gillies, R.M., 2003, Journal of Educational Psychology, 95(1), 137-147.

[7] Slavin, R.E., 2009, Cooperative Learning (Teori, Riset, dan Praktik). Terjemahan Nurulita Yusron, Bandung: Nusa Media.
[8] Sangadji, S., 2016, International Journal of Learning and Development, 1(6), 91-103.

[9] Ackay, N.O. \& Doymus, K., 2012, Journal of Educational Science Research, 2 (1): 109-123.

[10] Ciptaningtyas, A.N., Haryono, \& Masykuri, 2014, Jurnal Pendidikan Kimia (JPK), 2(3): 1-6.

[11] Miles, M. B., \& Huberman, A. M., 2009, Analisis Data Kualitatif Terjemahan Tjetjep Rohendi Rohidi, Jakarta, UI Press.

[12] Moleong, L.J., 2007, Metodologi Penelitian Kualitatif, Bandung, PT Remaja Rosdakarya.

[13] Wentzel, K.R., 1991, Review of Educational Research, 1(61): 1-24.

[14] Ryan, A.M., Hicks, L., \& Midgley, C., 1997, Journal of Early Adolescence, 2(17): 152-171. 